\section{Myopathy and Hypokalaemia in Carbenoxolone Therapy}

SIR,-We should like to report a case of myopathy and hypokalaemia associated with Duogastrone (carbenoxolone) therapy similar to that described by Dr. J. Forshaw (14 June, p. 674).

The patient was a 49-year-old woman who for many years had had intermittent dyspepsia. She was started on carbenoxolone $50 \mathrm{mg}$. four times a day by her general practitioner. After 13 days this had to be stopped because she had developed ankle oedema with breathlessness on mild exertion, orthopnoea, and basal crepitations. She was started on bendrofluazide, with improvement in her dyspnoea and ankle swelling. Several days later, however, she began to complain of pains in her hands and legs with weakness which was severe enough to prevent her climbing stairs. At this time she noticed that her urine was red, and because of this she was admitted to hospital for investigation of suspected haematuria.

Her urine was found to be red, and testing with Occultest was repeatedly positive. Red cells were not found on microscopy of the urine, but unfortunately spectroscopy was not carried out. She was found to have a severe hypskalaemic alkalosis with elevation of serum enzymes indicative of a myopathy [sodium 146; potassium <2; chloride $92 ; \mathrm{CO}_{3} 37(\mathrm{mEq} / \mathrm{l})$; blood urea $26 \mathrm{mg}$. $/ 100 \mathrm{ml}$.; S.G.O.T. 160 units/ ml. (normal 4-40); S.G.P.T. 120 units $/ \mathrm{ml}$. (normal 1-45), lactic acid dehydrogenase 344 m.units/ml. (normal <195); creatinine phosphokinase $759 \mathrm{~m}$.units $/ \mathrm{ml}$. (normal <31.2)]. Her E.C.G. initially showed changes due to hypokalaemia, but these resolved, leaving no evidence of myocardial damage.

Her potassium depletion was corrected using Slow-K (slow release tablets containing potassium chloride). Within five days her serum potassium was at the lower limit of normal (3.5 $\mathrm{mEq} / \mathrm{l}$.) and her symptoms had disappeared. She was allowed home, and when seen as an outpatient four weeks later her serum potassium was $4.5 \mathrm{mEq} / 1$. and her S.G.O.T. and S.G.P.T. were 19 units $/ \mathrm{ml}$. and 16 units $/ \mathrm{ml}$., respectively.

There is no doubt that this patient had a myopathy following carbenoxolone therapy. It also appears likely that she had myoglobinuria, although we do not have definite proof of this. Whether the myopathy is due to a direct " steroid-like" effect of carbenoxolone on the muscles, or whether it is a result of hypokalaemia, must remain speculative.

This case emphasizes the importance of giving potassium supplements to patients with fluid-retention due to carbenoxolone, particularly if diuretic therapy is also contemplated. -We are, etc.,

T. FYFE.

K. M. Cochran.

Medical Division. Glasgow S.2.
ictoria Infirmary,

T. B. BEGG.

SIR,-Dr. J. Forshaw (14 June, p. 674) and Dr. M. Swallow (26 July, p. 238) should not be surprised that profound hypokalaemia with muscle paresis could develop after prolonged treatment with carbenoxolone sodium in the form of Duogastrone capsules, as well as in the form of Biogastrone tablets. ${ }^{2}$ Formal metabolic studies ${ }^{2}$ of Duogastrone, $300 \mathrm{mg}$./day, have shown that the carbenoxolone sodium in these capsules is metabolically active, although in this study it was pointed out that this dose of $300 \mathrm{mg}$./day exceeded that usually recommended ( $200 \mathrm{mg} . /$ day).

Dr. Swallow suggests that " the occurrence of reversible hypertension and diminished glucose tolerance in the acute phase is compatible with the 'steroid-like' action of this drug." I would suggest that "steroid-like" is an imprecise description of the metabolic effects of carbenoxolone sodium. "Aldosterone-like " seems justifiable. ${ }^{2}{ }^{3}$-I am, etc.,

\section{J. H. Baron.}

Department of Surgery London W.12.

\section{REFERENCES}

Mohamed, S. D., Chapman, R. S., and Crooks, J., British Medical fournal, 1966, 1, 1581. Baron, J. H., and Nabarro, J. D. N., in a Symposium on Carbenoxolone Sodium, edited by
$\mathrm{J} . \mathrm{M}$. Robson and F. M. Sullivan, 1968, p. 127.

3 London, Butterworths. D. N., Slater, J. D. H., and 793 .

\section{Towel Clip Trauma}

SiR,-May I make an appeal to surgeons to consider avoiding the still widespread custom of including patients' skin when fastening towel clips? There are today, particularly with the advent of Steridrape, etc., many ways of safely securing sterile drapes.

When a surgical procedure is major, the essential clip injuries are of ten of only minor import to the patient. However, after minor procedures he often complains more of the clip wounds than of the surgical incision. Rightly so ; and many surgeons share my opinion, for these are so often avoidable.I am, etc., \section{King's College Hospital,
London S.E.S.}

\section{J. H. Williams.}

\section{Swedish Social Mores}

SIR,-I would like to correct the erroneous belief-evidently shared by the reviewer of Sex and Society in Sweden, Dr. M. Balin (31 May, p. 564)-that Sweden is a country with the highest alcohol consumption and highest incidence of alcoholism and suicide in the world. Many writers on these topics tend to accept this view uncritically without troubling to examine the evidence. The facts should adequately dispose of the myth.

So far as alcohol consumption is concerned, the Swedish population in 1963 drank alcoholic beverages which, when estimated as $100 \%$ alcohol, amounted to 5.8 litres per person aged 15 or over. Compared with France (18.7 litres), Italy (12.8 litres), Switzerland (9 litres), Australia (10 litres) United Kingdom ( $6 \cdot 2$ litres), and the U.S.A (8 litres), to name but a few countries, Sweden can hardly be said to be in the race. Estimates of prevalence rates for alcoholism are difficult to check, and most official figures can certainly be questioned. Mortality rates from cirrhosis of the liver certainly give no grounds for believing that Swedish alcoholism rates are particularly high compared with other western countries. World Health Organization sources show that for the years
1956-65, male death rates in Sweden from cirrhosis of the liver were 6.8 per 100,000 , to be compared with Austria (33.7), Chile $(42 \cdot 2)$, Italy $(26 \cdot 3)$, France $(42 \cdot 3)$, and Portugal $(32 \cdot 2)$. Other estimates of alcoholism prevalence rates place Sweden lower than France, Chile, the United States of America, Japan, Switzerland, and Yugoslavia, but on about the same level as Australia and Denmark.

When one turns to suicide, the Swedish rates are admittedly high (average 18.3 per 100,000 for the years 1955, 1960, and 1964). However, when compared with 27 other western countries, the Swedish rates are lower than those in Austria (23.1), Czechoslovakia (20.6), Denmark (21.9), Finland (20.1), West Germany (20), Hungary (24.7), and Switzerland (19.1). When comparing the average suicide rates for 1951 to 1956 with those in 1960 to 1964 , the Swedish rates show a nonsignificant increase (17.3 per 100,000 compared with $18 \cdot 2$ per 100,000$)$. This finding has to be compared with significant rises in Australia, Bulgaria, Ceylon, Columbia, Mexico, Denmark, Finland, and England and Wales for these two five-year periods. It would appear, therefore, that Swedish suicide rates and trends are not particularly striking compared with those obtained in other countries.

Dr. Balint implies in his review that high venereal disease and abortion rates in Sweden are in some way correlated with high alcoholism and suicide rates. If, in fact, there is no real evidence for these allegedly high alcoholism and suicide rates, it becomes essential that we should look elsewhere for explanation of some of the social pathology in Sweden as well as in a number of other countries.-I am, etc.,

F. A. WhitLock.

Department of Psychological Medicine,
University of Oueensland University of Queensland
Brisbane, Australia.

\section{Recognition of Voluntary Work in Hospitals}

SIR,-In 1962 the Ministry of Health's circular H.M.(62) 29 gave guidance to hospital authorities about the use of voluntary help in hospitals. The recommendations implied that voluntary service in hospital could make a valuable contribution to the welfare of the patients. Since then voluntary work in hospitals has justified itself.

At present a National Health Service which welcomes voluntary aid has no generally accepted system of acknowledging it. Volunteers do not give their services for reward, but it is satisfying for them and the hospital authorities if their activities can be given some official token of appreciation. Some hospitals have designed their own lapel badges, for example, or a certificate which can be awarded to voluntary workers who have given a specified amount of assistance, but in other places voluntary helpers may receive no permanent record of gratitude for their efforts.

The appropriate recognition of voluntary help throughout the National Health Service would invite and encourage more voluntary service.-I am, etc.,

$$
\text { D. A. SPENCER. }
$$
Stansfield View Hospital,
Todmorden, Lancs. 